\title{
Türkiye'de Medikal Sektörde Yer Alan KOBİlerin Ar-Ge ve Yenilik Faaliyetlerinde Devlet Desteklerinin Etkisi (The Effect of Government Subsidies on Innovation Activities of Medical SMEs in Turkey)
}

\author{
Aybüke YALÇIN iD a Burak ÇETIN (iD b \\ a Ankara Hacı Bayram Veli Üniversitesi, Tapu Kadastro Yüksekokulu, Ankara, Türkiye. aybuke.yalcin@hbv.edu.tr \\ b Ankara Hacı Bayram Veli Üniversitesi, Polatlı Sosyal Bilimler Meslek Yüksekokulu, Ankara, Türkiye. burak.cetin@hbv.edu.tr
}

\begin{tabular}{|c|c|}
\hline MAKALE BİLGİSİ & ÖZET \\
\hline Anahtar Kelimeler: & Amaç - Çalışma, Türkiye'de medikal sektörde faaliyet gösteren, medikal ürün üreten küçük ve orta \\
\hline Devlet Destekleri & ölçekli işletmelerin (KOBİ) yenilik (Ar-Ge) ve araştırma-geliştirme faaliyetlerinde devlet desteklerinin \\
\hline Küçük ve Orta Ölçekli & etkisini ve devlet desteklerinden ne derece faydalandıklarını ele almayı amaçlamaktadır. \\
\hline İşletmeler & Yöntem - Çalışmada, Ankara ve İstanbul'da medikal sektörde faaliyet gösteren yedi küçük ve orta \\
\hline Yenilik & ölçekli işletmeye ulaşılmıştır. Veriler, nitel araştırma yöntemlerinden biri olan "çoklu durum analizi" \\
\hline Medikal Sektör & $\begin{array}{l}\text { uygulanılarak incelenmiştir. Çalışmanın temel problemine ilişkin detaylı bilgi elde edebilmek için } \\
\text { çalışmada verilerin toplanması için işletme yöneticileri/sahipleri ile görüşülerek görüşme yöntemi } \\
\text { kullanılmıştır. }\end{array}$ \\
\hline
\end{tabular}

Gönderilme Tarihi 25 Haziran 2021

Revizyon Tarihi 20 Ağustos 2021

Bulgular - Yapılan çalışmadan elde edilen verilere dayanarak, KOBI'lere sunulan devlet yardımlarına ilişkin genel bir değerlendirme ile önerilerde bulunulmaktadır. Çalışma kapsamında ortaya çıkan önemli sonuçlar, yenilik ve Ar-Ge faaliyetleri için finansal kaynakların önemli olduğu, yenilik ve rekabet üstünlüğü elde etmede kaynakların sınırlı olması, devlet desteklerinin yeterli olmadığı, bürokratik prosedür fazlalığı ve yavaşlık sebebiyle devlet desteklerinden yeterince yararlanamamalarıdır. Devlet desteklerine getirilecek düzenlemeler ve geliştirmeler ile birlikte KOBİlerin daha yenilikçi olacakları sonucuna ulaşılmıştır.

Makale Kategorisi:

Tartışma - Sonuç olarak, Ar-Ge ve yenilik yapma eğiliminde olan işletmelerin ihtiyaç duydukları Araştırma Makalesi kaynaklara erişebilmeleri ve daha yenilikçi olabilmeleri adına devlet destek ve teşviklerinin önemli olduğu ortaya konmuştur.

\begin{tabular}{ll}
\hline ARTICLE INFO & ABSTRACT \\
\hline Keywords: & $\begin{array}{l}\text { Purpose }- \text { The study aims to examine the effect of government support in innovation (R\&D) and } \\
\text { research and development activities of small and medium-sized enterprises (SMEs) operating in the } \\
\text { Government Subsidies }\end{array}$ \\
$\begin{array}{l}\text { medical sector and producing medical products and to what extent they benefit from government } \\
\text { Enterprises }\end{array}$ & support.
\end{tabular}

Innovation

Medical Sector

Received 25 June 2021

Revised 20 August 2021

Accepted 30 August 2021

Article Classification:

Research Article
Design/methodology/approach - In the study, we reached seven SMEs operating in the medical sector in Ankara and Istanbul. The data were analyzed by applying multiple case analyses, which is one of the qualitative research methods. In order to obtain detailed information about the main problem of the study, the interview method was used by interviewing the business managers/owners to collect the data in the study.

Findings - Based on the data obtained from the study, which proposed suggestions with a general evaluation regarding the government supports offered to SMEs. The significant results that emerged within the scope of the study are that financial resources are crucial for innovation and R\&D activities, resources are limited in achieving innovation and competitive advantage, government supports are not sufficient, and they have not benefited sufficiently from the government supports due to bureaucratic procedures and slowness. It has concluded that SMEs will be more innovative with the regulations and developments regarding government supports.

Discussion - As a result, the study has concluded that government support and incentives are crucial for businesses that tend to make R\&D and innovation, access the resources they need, and be more innovative. 


\section{Giriş}

Küçük ve orta ölçekli işletmeler ${ }^{1}(\mathrm{KOBI})$, her geçen gün artan sayıları ile ekonominin temel unsurlarından biri haline gelmeye başlamıştır. Dünya genelinde önemli bir paya sahip olan KOBI'ler, 2019 yılında Türkiye'de toplam işletmelerin \%99.8'ini (TÜIK, 2020) oluşturmaktadır. İstihdam ettiği kişi sayısı ve sahip oldukları maddi kaynaklara göre sınıflandırılan KOBİler genellikle imalat, hizmet, ticaret ve tarım işletmeleri olarak faaliyet gösteren heterojen bir işletme grubudur. Bazıları dinamik, yenilikçi ve büyüme odaklıyken bazıları daha küçük, aile işletmelerinden oluşabilmektedir (Lukács, 2005). KOBİ'ler çoğunlukla, değişen koşullara hızla uyum sağlama yetenekleri ve esneklik düzeylerinin yüksek olmasından dolayı yeniliğin itici gücü olarak kabul edilmektedir (Auer ve Jarmai, 2018). Ekonomik büyüme ve kalkınma konusunda kritik rol oynayan KOBİler için yenilik faaliyetleri, KOBİlerin gelişmeleri ve rekabet üstünlüğü elde etmeleri açısından önemlidir. Yenilikler, işletmelerin hayatta kalmasına, büyümelerinin hızlanmasına, verimliliklerinin artmasına ve bunun sonucunda yenilikçi olmayanlara kıyasla daha kârlı olmalarına yardımcı olmaktadır. Sürekli değişen bir ortamda sürdürülebilir rekabet avantajının önemli kaynaklarından biri olarak kabul edilmektedir (Köker \& Alan, 2021). Dolayısıyla yeniliğin işletmelerin hayatta kalabilmesinde bu derece önemli olması iç ve dış pazar ağı açısından daha sağlam ülke ekonomilerinin oluşturulmasına da imkân sağlamaktadır (Gültekin ve Onuk, 2020).

Araştırma ve geliştirme $(\mathrm{Ar}-\mathrm{Ge})^{2}$ yoluyla yeni bilgi üretme yeteneğinin, genellikle işletmelerin yenilik başarısı için kilit bir rol oynadığı kabul edilir (Rammer, Czarnitzki ve Spielkamp, 2009). Ar-Ge ve yenilik birbirleri ile ilişkili olmalarına rağmen her Ar-Ge faaliyeti sonucu yenilik oluşmadığı gibi her yenilikte Ar-Ge faaliyeti sonucu ortaya çıkmamaktadır. Ar-Ge bir bilgi ile yeni ürünler, uygulamalar ve üretim süreçleri ortaya koyma amacıyla yapılan çalışmalar iken yenilik Ar-Ge sürecinin de dâhil olduğu araştırmadan, geliştirmeye ve ticarileştirmeye kadar olan tüm süreci kapsamaktadır (Güler ve Kanber, 2011). KOBI'lerin, daha fazla yenilikçi, Ar-Ge faaliyetleri içerisinde bulunan, nitelikli ürün üreten ve üretilen ürünleri ticarileştirebilen, diş pazarlara ürünlerini sunabilen konuma gelebilmelerinde devlet destek ve/veya teşviklerinin önemli bir katkı sağlayacağı düşünülmektedir.

Bilgi yoğun sektörlerde faaliyet gösteren işletmelerin sahip oldukları ürün/süreç yenilikçiliği ve pazar odaklı girişimcilik faaliyetleri sayesinde bulundukları sektöre önemli katkı sağlamaktadırlar (Tur-Mas ve Soriano, 2014: 51-52; Garcia-Quevedo, Mas-Verdu ve Montolio, 2013). Bilgi yoğun sektörlerden biri olan medikal sektör, genellikle Ar-Ge'ye duyarlı olmasıyla bilinmektedir ve düşük teknolojiliden yüksek teknolojili ürünlere kadar çeşitli ürünler üreten KOBI'ler ile çok uluslu işletmeler (KOBİlere kıyasla çok daha az sayıda) ile karakterize edilmektedir (Auer ve Jarmai, 2018). Medikal cihaz ve ürünlerin kullanımında bilgi ve yenilik önemlidir. Risklerin ve sonuçların yüksek bulunduğu medikal cihaz ve ürünlerinde yenilikçi yatırımın büyümede ciddi etkisi bulunmaktadır (Kılıçarslan ve Takkasız, 2019).

Türkiye' de işletmelerin neredeyse çoğunu KOBİ'lerin oluşturması, KOBİ'lerin yer aldığı sektörler açısından ise medikal sektörün dinamik, çok hızlı büyüyen, sağlık sektörünün de önemli bir bileşeni olan bilgi yoğun bir sektör olması çalışmanın medikal KOBI'ler üzerine yapılmasında etkili olmuştur. Çalışmada, KOBİ’lerin devlet desteklerinden ne derece faydalandıkları ve karşılaştıkları sorunlara değinilmektedir. Makalenin ana amacı "Devlet teşviklerinin Medikal Kobilerin Ar-Ge ve yenilik faaliyetleri üzerinde nasıl bir etkisi vardır?" sorusuna cevap bulabilmektir. Araştırma sorusuna cevap bulabilmek adına, çalışmada medikal sektörde bulunan KOBI'lerin yenilik faaliyetleri ve bu faaliyetler kapsamında Ar-Ge çalışmaları ve yatırımları konusunda nasıl bir konumda oldukları, bakış açıları, faaliyetlerini gerçekleştirirken devlet yatırımlarından

\footnotetext{
1 "Küçük ve Orta Büyüklükteki İşletmelerin Tanımı, Nitelikleri ve Sınıflandırılması Hakkında Yönetmelik" ile KOBI’ler, yılda en fazla 250 kişi istihdam eden, yıllık net satış hasılatı veya mali bilançosundan herhangi biri 125 milyon TL'sini aşmayan, mikro, küçük ve orta büyüklükteki işletme olarak sınıflandırılan ekonomik birimler veya girişimler olarak tanımlanmaktadır (www.kosgeb.com.tr).

2 Frascati kılavuzuna göre Ar-Ge; insan, kültür ve toplumun bilgisinden oluşan bilgi dağarcığının artırılması ve bu dağarcığın yeni uygulamalar tasarlamak üzere kullanılması için sistematik temelde yürütülen yaratııı çalışmalar" olarak tanımlanmaktadır (www.tubitak.gov.tr).
} 
faydalanıp faydalanmadıkları ve eğer faydalanıyorlarsa faaliyetlerine ve yenilik çıktılarına ne gibi etkisinin olduğu araştırılmaktadır.

\section{Kavramsal Çerçeve}

Hızla değişmekte ve gelişmekte olan medikal uygulamalarda, yeni prosedürler ve teknolojinin standart hale gelmesi için yoğun bir kaynak aktarımı ve zaman gerekmektedir. Sağlık sektörü gibi medikal sektör de bilgi yoğun bir sektördür ve sektörün, hizmet ettiği sağlık, toplumun refahı, işgücü katılımı, yatırım oranları ile diğer beşeri faktörler üzerinde doğrudan etkisi bulunmaktadır (Antonia ve Zamora, 2000; Taban, 2006:33). Medikal ürünlerin Ar-Ge çalışmaları yüksek risk içermekle birlikte (Bergsland, Elle ve Fosse, 2014) medikal ürün yeniliği ile hem toplumsal hem de ekonomik anlamda fayda elde edilebilmektedir. Dolayısıyla bilgi yoğun bir sektör olan medikal sektörde teknoloji ve yenilik, sektörün can damarıdır (Scherer,1980; Claire,2004; Xin, Yeung ve Cheng, 2010). Hasta bakımında kullanılmak üzere medikal ürünlerin geliştirilmesi, hasta odaklı değer yaratma gibi yeniliklerde, sağlık sunucuları ve sağlık hizmeti kullananları için, verilerin kullanımında ve yenilik süreçlerinin iyileşmesinde tetikleyici rol oynamaktadır (Deloitte, 2021). Oldukça geniş bir ürün yelpazesi ve teknolojiyi bünyesinde barındıran medikal sektörde 11.000'in üzerinde farklı ürün çeşidi mevcut olup bu ürünleri elde etmek için oldukça farklı teknolojiler kullanılmaktadır (Türkiye İlaç ve Tıbbi Cihaz Kurumu, 2015). Küresel ölçekli bakıldığında medikal ürün pazarı 2019 yılında 597 milyar USD olarak gerçekleşmiş ve küresel ticaretin \%1.7'sine denk gelmektedir. Türkiye'de, tıbbi kullanıma uygun hammadde üretim ve plastik ağırlıklı tıbbi malzeme üretim teknolojisinin, hidrolik pnömatik devre elemanları ve dişli aksamları üretiminin, kalıpçılığın ve elektronik montaj sanayinin gelişmiş olması gibi etmenler sebebiyle medikal ürün sanayini destekleyen bir potansiyel oluşabilmektedir (Kiper,2018). Fakat bu potansiyele rağmen yurtiçi pazarda oluşan medikal ürün ihtiyacının \%85'i ithal ürünlerden karşılanmaktadır (Köse ve Çifter, 2018). Dolayısıyla medikal ürünlerde dışa bağımlılığın azalması, ithalatçı konumdan ihracatçı konuma geçebilmesi için işletmelerin, yenilikçilik düzeylerinin artmasına, Ar-Ge faaliyetlerine yoğunlaşmalarına yardımcı olacak devlet desteklerinin düzenlenmesi, arttıılması ülke ekonomisi adına oldukça önemlidir. Türkiye'de medikal sektörde yer alan KOBI'lerin yenilik ve Ar-Ge faaliyetlerinde bulunmalarının önemi sebebiyle çalışmada, KOBİlerin faaliyetlerini gerçekleştirirken ne derece devlet destek ve/veya teşviklerinden faydalandıkları araştırılmaktadır. Alan yazın incelendiğinde Türkiye'de medikal sektörde faaliyet gösteren KOBİler özelinde yapılan çalışmalar ile aynı zamanda bu KOBİ'lerin devlet ile olan ilişkisi ve devlet desteklerinin yenilik yönelimine olan etkisinin ve rolünün incelendiği çalışmalar oldukça kısıtlıdır. Dolayısıyla çalışmadan elde edilen sonuçların ileride yapılacak olan çalışmalara rehberlik edeceği düşünülmektedir.

\subsection{Yenilikçilik ve Ar-Ge Yatırımları}

Yenilik kavramı, birimin (yenilikten sorumlu aktör) önceki ürün ve süreçlerinden önemli şekilde farklılaşması ve potansiyel kullanıcıların (ürün) kullanabildiği veya birim (süreç) içerisinde geliştirilen, ürün veya süreçlerin yenilik veya geliştirilme (veya birleştirilmesi) süreci olarak tanımlanmaktadır. Oslo Kılavuzu'na göre ise yenilik, "işletme içi uygulamalarda, işyeri organizasyonunda veya dış ilişkilerde yeni veya önemli derecede iyileştirilmiş bir ürün veya süreç, yeni bir pazarlama yöntemi ya da yeni bir organizasyonel yöntemin gerçekleştirilmesidir". Yenilik faaliyetleri tüm geliştirme, finansal ve ticari faaliyetleri içermektedir (OECD, 2018). Rekabet üstünlüğü sunan yenilik, iki ana kaynağın sonucudur: (1) işletmenin bilgi birikimi çerçevesinde işletme içi Ar-Ge ve (2) diğer işletmelerin yeniliklerinin taklididir (Knight ve Cavusgil,2004:126). İşletmelerin yenilik kültürü, stoklanmış bilgi birikimleri, ürün geliştirme ve/veya iyileştirme ve yeni iş yöntemleri ile ortaya çıkmaktadır (Dosi,1988). Yenilikçi işletmeler; yönetim, insan kaynakları, pazarlama, finansman, üretim verimlilikleri, hükümet programı ve hizmetlerine yenilikçi olmayan işletmelerden daha fazla önem vererek ve daha yoğun faaliyetler sürdürerek yenilikçi olmayan işletmelere göre daha başarılı

\footnotetext{
${ }^{3}$ Oslo Kılavuzu, yenilik faaliyetlerinde kullanılacak ölçeğin belirlenmesi ve yenilik odaklı işletmelerin yenilikçiliklerine etki edecek sistematik ve içsel etmenlerin özelliklerini anlamayı hedefleyen, yenilik faaliyetlerini ve yeniliği tanımlayan, sektördeki yenilik faaliyetlerine yönelik verileri toplayan ve yorumlayan en temel uluslararası kılavuzdur (www.oecd.org).
} 
A. Yalçın - B. Çetin 13/3 (2021) 2607-2622

olmaktadırlar (Baldwin ve Johnson, 1995). Yenilik, ilgili paydaşlar ile ilişkiler oluşturularak ve bu ilişkileri sürdürmek için varlıklar, beceri ve yeteneklerin kombinasyonundan oluşan strateji ve kararlar içeren başarılı iş modeli seçimidir (Vrontis, Basile, Andreano, Mazzitelli ve Papsolimou, 2020). Yeniliğin temel koşulları; ArGe ekipleri arası işlevsellik, yeni ürün geliştirme rutinleri, kalite kontrol prosedürleri ve performans ölçüm sistemleridir (Eisenhardt ve Martin,2000). Medikal KOBI'lerin yenilikçilik boyutu üzerine yapılan çalışmalar Tablo 1'de gösterilmektedir.

Tablo 1: Medikal KOBI’lerin yenilikçilik boyutu üzerine yapılan çalışmalar

\begin{tabular}{|c|c|}
\hline YAZAR VE YAYIN YILI & SONUÇ \\
\hline $\begin{array}{l}\text { Pullen, J.J. A., } \\
\text { Weerd-Nederhof, P. C., } \\
\text { Groen, A. J. ve } \\
\text { Olaf, F. A.M. (2012) }\end{array}$ & $\begin{array}{l}\text { Medikal ürün üreten çoğu KOBI'lerin yenilik } \\
\text { performansını belirleyen ana faktörler, kaynak, güven, iş } \\
\text { ağının güçlü olması, yeni ürün geliştirme potansiyeli ve } \\
\text { sürdürülebilirliktir. }\end{array}$ \\
\hline Auer, A. ve Jarmai K. (2018) & $\begin{array}{l}\text { Medikal ürün üreten KOBİ'lerin araştırma ve yenilik } \\
\text { sorumlulukları farkındalığı, günlük kullandığı } \\
\text { uygulamalar ve iyileştirmeler, gelecekte elde edecekleri } \\
\text { spesifik iyileştirmeler ve organizasyonel yeniliklerinde } \\
\text { etkilidir. }\end{array}$ \\
\hline Sass, M.(2012) & $\begin{array}{l}\text { Yenilikçi medikal KOBI'ler, teknoloji kullanımı, } \\
\text { pazarlama, organizasyon yapısı ve rekabetçi ürünler ile } \\
\text { daha hızlı uluslararasılaşmaktadır. }\end{array}$ \\
\hline Larsen P. ve Lewis, A.(2007) & $\begin{array}{l}\text { Medikal ürün yeniliği yapan KOBI'ler incelendiğinde } \\
\text { finansal yapı ve KOBİ'nin yenilik kültürü en önemli } \\
\text { engeldir. KOBİ'nin lokasyon seçimi, global dağıtım, } \\
\text { yetenek edinimi, hedef Pazar analizi, araştırma yönetimi } \\
\text { ve koruma KOBİ'nin yenilik sürecinde engeller olarak } \\
\text { belirlenmiştir. }\end{array}$ \\
\hline $\begin{array}{l}\text { Davey, S.M., Brennan, M., Meenan, B.J. ve } \\
\text { McAdam R.(2011) }\end{array}$ & $\begin{array}{l}\text { Medikal ürün sektöründe yenilik sürecinde, yönetici, } \\
\text { mühendis, bilim insanı ve hatta hastalar gibi tüm } \\
\text { paydaşların fikri alınarak daha faydalı bir süreç organize } \\
\text { edilmesi yararlı olacaktır. }\end{array}$ \\
\hline Zeng, S.X., Xie X.M. ve Ta, C.M.(2010) & $\begin{array}{l}\text { Medikal ürün üreten KOBI'lerin devlet ile yapılan } \\
\text { işbirlikleri sanılanın aksine KOBİ'lerin yenilik } \\
\text { performansını olumsuz etkilememektedir. Yenilik } \\
\text { sürecinde tedarikçiler, diğer işletmeler ve son tüketiciler } \\
\text { daha farklı rol oynamaktadır. }\end{array}$ \\
\hline $\begin{array}{l}\text { Daiberl, C. F., Oks, S. J., Roth, A., Möslein, K. } \\
\text { ve Alter, S. (2019) }\end{array}$ & $\begin{array}{l}\text { Medikal ürün kümeleri incelendiğinde dört ana faktörün } \\
\text { KOBİlerin yeniliklerini etkili oldukları ortaya çıkmıştır. } \\
\text { Etkili olan faktörler: yöneticilerin kararlar, yenilik } \\
\text { fırsatlarının anlaşılmaması, paydaşların sorumluluklar } \\
\text { ve iletişimsizlik yenilik sürecini engelleyen faktörlerdir. }\end{array}$ \\
\hline $\begin{array}{l}\text { Walters, A., Thomas, N., Brown, R. ve Lewis, } \\
\text { A. (2001) }\end{array}$ & $\begin{array}{l}\text { Medikal KOBI'lerde yeniliğin başarısızlığı jenerik } \\
\text { problemlerden kaynaklanmaktadır. Bunlar, tasarım } \\
\text { çalışmasının eksikliği, yetersiz iletişim, deneyim ve } \\
\text { uzmanlık eksikliği ve yenilik kültürünün } \\
\text { oluşmamasıdır. }\end{array}$ \\
\hline
\end{tabular}

Ar-Ge ekonomik kalkınmanın anahtarıdır. Ülkelerin gelişmişlik düzeyinin bir göstergesi de Ar-Ge harcamalarına ayırdıkları kaynakların büyüklüğü ile de ölçülmektedir. Gelişmiş ülkeler arasındaki rekabet üst noktalarda yaşanırken gelişmekte olan ülkeler kaynak yetersizliği ya da sorununun önem ve ağırlığını 
henüz kavrayamadıkları için araştırma ve geliştirme çalışmalarında, dolayısıyla da rekabette geri planda kalmaktadır (Tarım,2014). Yenilik kapsamında Ar-Ge yatırımlarının öncelikli amacı maliyetleri düşürmek ve yenilik çıktılarını artırmaktır. Ar-Ge yatırımları, KOBİ'lerin yenilikçi faaliyetlerini destekleme yöneliktir (Türkiye Cumhuriyeti Kalkınma Bakanlığı, 2018; Yülek ve Daş, 2016). Genel olarak kaynaklar bakımından kısıtlı imkânlara sahip olan KOBİ'ler Ar-Ge ve yenilik faaliyetleri için bilgiye, insan kaynağına ve sermayeye ihtiyaç duymaktadırlar. Yaşanan iç ve dış sermaye eksikliği bir KOBI'nin Ar-Ge ve yenilikçi olma yönündeki en bağlayıcı kısıtlaması olarak kabul edilmektedir (Okamuro, H., Nishimura, J., Colombo, M., ve Stam, E., 2019). Kaynak yetersizliği sebebiyle KOBI'lerin faaliyetlerini hayata geçirememelerini engellemede devlet destekleri oldukça önemli bir rol oynamaktadır. Çünkü devlet destekleri, KOBİlerin Ar-Ge yatırımlarını, patent gibi yenilik çıktılarını olumlu yönde etkilemektedir (Almus ve Czarnitzki 2003; Hyytinen ve Toivanen 2005; Koga, 2005). Birçok çalışmada da KOBİ'lerin farklı kalemler noktasında devlet yatırımları ile desteklendiğini belirtmektedir. Literatürde yer alan çalışmalarda devlet destekleri; yeni ürün tanıtımında (Bérubé ve Mohnen, 2009), Ar-Ge finansmanında (Meuleman ve De Maeseneire, 2008; Klette ve Moen, 2011; Manez vd. 2014), patent faaliyetlerinde (Bronzini ve Piselli, 2016), işgücü verimliliğinde (Karhunen ve Huovari, 2015) ve yatırım destekleme aracı olarak (Kleer, 2010) kullanılmaktadır.

\subsection{Türkiye'de Ar-Ge Yatırımları ve Kobilere Yönelik Devlet Desteği}

Türkiye Ar-Ge harcamaları bakımından önemli atılımlar gerçekleştirmiştir. 2019 yılında Ar-Ge harcaması 45.954 Milyar TL (24.974 milyar USD) olarak gerçekleşmiş ve GSYH'daki payı \%1.06'seviyesine ulaşmıştır (Tüik,2021). Ülkelerin çoğu, işletmelerin Ar-Ge yatırımlarını, yenilik süreçlerinde karşılaşacakları maliyetleri ve işletmelerin Ar-Ge faaliyetlerini kolaylaştırıı olması açısında farklı politikalar uygulamaktadır (örn; vergi indirimi, devlet teşvikleri). Türkiye, devlet tarafından KOBİ'leri üç farklı düzeyde desteklemektedir. İlk olarak Ticaret Bakanlığı tarafından mal ve hizmet üretimi yapan işletmelere yönelik olarak; fuar, pazara giriş, pazar araştırması, uluslararası rekabetçiliğin geliştirilmesi, markalaşma ve Turquality, yurtdışı birim, marka ve tanıtım, tasarım, özel statülü şirketler, tarımsal ürünler, döviz kazandırıcı hizmetler ve dijital faaliyetlere ilişkin destekler gibi farklı kalemlerde desteklemektedir (Ticaret Bakanlığı,2021). Diğer destek kurumu Türkiye Bilimsel ve Teknolojik Araştırma Kurumu (TÜBİTAK) tarafından yapılan proje temelli desteklerdir. TÜBİTAK'ın sunduğu destekler, KOBİ'lere dönük, girişimcilik, yenilikçilik, Ar-Ge projeleri, öncelikli alanlar, laboratuvar destek, patent destekleri sunana ulusal ve uluslararası destekli proje temelli desteklerdir (TÜBİTAK,2021). Üçüncü destek kurumu, KOBİlere sunduğu devlet destekleri Küçük ve Orta Ölçekli İşletmeleri Geliştirme ve Destekleme İdaresi Başkanlığı (KOSGEB) tarafından yapılmaktadır. Yapılan destekler Ar-Ge, teknolojik üretim ve yerlileştirme başlıkları altında belirlenmiştir. Bu desteklerin ana çerçevesi; Ar-Ge ve yenilik kapsamında yeni fikir, buluş, süreç-hizmet üretimi ve iyileştirme ve ürün geliştirme (Ür-Ge) faaliyetleri ile değişen pazar taleplerine ve teknolojik gelişmelere uyum sağlamaları amacıyla, KOBİler tarafından orijinal, iyileştirilmiş veya değiştirilmiş yeni ürünlerin üretilmesini amaçlayan destek programıdır (Resmi Gazete, 2010:27612). KOSGEB'in sunduğu destek kapsamları ve miktarları Tablo 2'de gösterilmektedir.

Tablo 2: Ar-Ge ve Yenilik Kapsamında KOSGEB Destek Türleri

\begin{tabular}{|c|c|c|c|c|c|}
\hline DESTEK TÜRÜ & $\begin{array}{l}\text { Ar-Ge, Ür- } \\
\text { Ge ve } \\
\text { YENILİK } \\
\text { DESTEK } \\
\text { PROGRA } \\
\text { MI }\end{array}$ & $\begin{array}{c}\text { AR-GE ve } \\
\text { YENILIIK } \\
\text { DESTEK } \\
\text { PROGRA } \\
\text { MI }\end{array}$ & $\begin{array}{c}\text { Ar- Ge, } \\
\text { YENILIKK ve } \\
\text { ENDÜSTRIY } \\
\text { EL } \\
\text { UYGULAMA } \\
\text { DESTEK } \\
\text { PROGRAMI }\end{array}$ & $\begin{array}{c}\text { KOBİ } \\
\text { TEKNO } \\
\text { YATIRIM- } \\
\text { KOBİ } \\
\text { TEKNOLOJI } \\
\text { K ÜRÜN } \\
\text { YATIRIM } \\
\text { DESTEK } \\
\text { PROGRAMI } \\
\end{array}$ & $\begin{array}{c}\text { STRATEJI } \\
\text { K ÜRÜN } \\
\text { DESTEK } \\
\text { PROGRA } \\
\text { MI }\end{array}$ \\
\hline $\begin{array}{l}\text { Makine-Teçhizat, } \\
\text { Donanım, } \\
\text { Hammadde, Yazılım }\end{array}$ & $\checkmark$ & $\checkmark$ & $\checkmark$ & $\checkmark$ & $\checkmark$ \\
\hline
\end{tabular}


A. Yalçın - B. Çetin 13/3 (2021) 2607-2622

\begin{tabular}{|c|c|c|c|c|c|c|}
\hline \multirow{6}{*}{$\begin{array}{c}\text { İŞLETME } \\
\text { DESTEKLERİ }\end{array}$} & $\begin{array}{l}\text { ve Hizmet Alımı } \\
\text { Giderleri Desteği }\end{array}$ & & & & & \\
\hline & $\begin{array}{l}\text { Makine-Teçhizat, } \\
\text { Donanım, } \\
\text { Hammadde, Yazılım } \\
\text { ve Hizmet Alımı } \\
\text { Giderleri Desteği } \\
\text { (Geri Ödemeli) }\end{array}$ & $\checkmark$ & $\checkmark$ & $\checkmark$ & $\checkmark$ & $\checkmark$ \\
\hline & $\begin{array}{l}\text { Üretim Hattı Tasarım } \\
\text { Giderleri Desteği }\end{array}$ & $\checkmark$ & $\checkmark$ & $\checkmark$ & $\checkmark$ & $\checkmark$ \\
\hline & $\begin{array}{l}\text { Nitelikli Personel } \\
\text { Giderleri Desteği }\end{array}$ & $\checkmark$ & $\checkmark$ & $\checkmark$ & $\checkmark$ & $\checkmark$ \\
\hline & $\begin{array}{l}\text { Referans Numune } \\
\text { Gideri Desteği }\end{array}$ & $\checkmark$ & $\checkmark$ & $\checkmark$ & $\checkmark$ & $\checkmark$ \\
\hline & $\begin{array}{l}\text { Hizmet Alımı } \\
\text { Desteği }\end{array}$ & $\checkmark$ & $\checkmark$ & $\checkmark$ & $\checkmark$ & $\checkmark$ \\
\hline \multirow{10}{*}{$\begin{array}{c}\text { PROJE } \\
\text { GELISSTTIRME } \\
\text { DESTEĞi }\end{array}$} & $\begin{array}{l}\text { Sinai Mülkiyet } \\
\text { Hakları Giderleri } \\
\text { Desteği }\end{array}$ & $\checkmark$ & $\checkmark$ & $\checkmark$ & & \\
\hline & $\begin{array}{l}\text { Proje Danışmanlık } \\
\text { Desteği }\end{array}$ & & $\checkmark$ & $\checkmark$ & $\checkmark$ & \\
\hline & Eğitim Desteği & & $\checkmark$ & $\checkmark$ & $\checkmark$ & \\
\hline & Proje Tanıtım Desteği & & $\checkmark$ & $\checkmark$ & & \\
\hline & $\begin{array}{l}\text { Yurtiçi ve Yurtdışı } \\
\text { Kongre/Konferans/F } \\
\text { uar Ziyareti/ } \\
\text { Teknolojik İşbirliği } \\
\text { Ziyaret Desteği } \\
\end{array}$ & & $\checkmark$ & $\checkmark$ & & \\
\hline & $\begin{array}{l}\text { Test, Analiz ve } \\
\text { Belgelendirme } \\
\text { Giderleri Desteği }\end{array}$ & $\checkmark$ & $\checkmark$ & $\checkmark$ & & \\
\hline & $\begin{array}{l}\text { Diğer Giderler } \\
\text { Desteği }\end{array}$ & $\checkmark$ & $\checkmark$ & $\checkmark$ & & \\
\hline & $\begin{array}{l}\text { Tanitım ve } \\
\text { Pazarlama Giderleri } \\
\text { Desteği }\end{array}$ & & & & $\checkmark$ & \\
\hline & Kira Desteği & $\checkmark$ & $\checkmark$ & $\checkmark$ & & \\
\hline & $\begin{array}{l}\text { Başlangiç Sermayesi } \\
\text { Desteği }\end{array}$ & & $\checkmark$ & $\checkmark$ & & \\
\hline \multirow{4}{*}{$\begin{array}{l}\text { ENDÜSTRIY } \\
\text { EL } \\
\text { UYGULAMA } \\
\text { PROGRAMI }\end{array}$} & Kira Desteği & & & $\checkmark$ & & \\
\hline & $\begin{array}{l}\text { Makine-Teçhizat, } \\
\text { Donanım, } \\
\text { Hammadde, Yazılım } \\
\text { ve Hizmet Alımı } \\
\text { Giderleri Desteği }\end{array}$ & & & $\checkmark$ & & \\
\hline & $\begin{array}{l}\text { Makine-Teçhizat, } \\
\text { Donanım, } \\
\text { Hammadde, Yazılım } \\
\text { ve Hizmet Alımı } \\
\text { Giderleri Desteği } \\
\text { (Geri Ödemeli) }\end{array}$ & & & $\checkmark$ & & \\
\hline & $\begin{array}{l}\text { Personel Gideri } \\
\text { Desteği }\end{array}$ & & & $\checkmark$ & & \\
\hline
\end{tabular}

Kaynak: KOSGEB, Ar\&Ge, Teknolojik Üretim ve Yerlileştirme Destekleri, 2021

Özet olarak, bakanlık seviyesinden kurum seviyesine kadar farklı kanallar ile KOBİ'ler desteklenmektedir. Özellikle yenilikçilik, Ar-Ge, yeni ürün üretimi, geliştirilmesi, öncelikli alanlar, girişimcilik, yurtdışı pazar ve 
A. Yalçın - B. Çetin 13/3 (2021) 2607-2622

pazar araştırma gibi farklı kalemlerde KOBİ'ler devlet desteği almaktadır. Bu destekler, KOBİ'lerin Ar-Ge faaliyetlerini kolaylaştırmak, yenilikçi ürünler üretmek ve işletmelerin uluslararası pazar(lar)da rekabetçi üstünlük elde etmelerini sağlamaya yönelik desteklerdir.

\section{Yöntem}

\section{1. Çalışmanın Amacı ve Önemi}

Çalışmanın amacı, Türkiye' de bulunan ve medikal sektörde yer alan KOBİ'lerin yenilik faaliyetlerinde devlet desteklerinin nasıl bir rolü olduğunu incelemektir. Medikal alanda yer alan KOBI'lerin yenilik faaliyetlerinde devlet desteklerinin nasıl olduğu sorusu çalışmanın ana problemini oluşturmaktadır. Çalışmada, yüksek teknoloji ve bilgi gerektiren sektörlerden biri olan medikal sektörün seçilme sebebi, sektörde yer alan işletmelerin yenilik faaliyetleri ve devlet desteklerinin rolü noktasında yeterli çalışmanın bulunmamasıdır. Çalışmada ana problemin anlaşılmasına yönelik sorular literatürdeki çalışmalar (De Jong ve Marsili, 2006; Knight ve Cavuşgil, 2004; Lumpkin ve Dess, 1996; Hughes ve Morgan, 2007; Stone, 2008; Rialp, Rialp, Urbano ve Vaillant, 2005; Efrat, Gilbao ve Yonatany, 2017) dikkate alınarak oluşturulmuştur KOBİlere sorulan sorular aşağıdaki gibidir.

- Yenilik yapmaya zaman ayırır mısınız? Sizin için yenilik yapmak neden önemlidir?

- Son 3 yıl içerisinde ortaya koymuş olduğunuz ürün ve/veya süreç yeniliğiniz var mı?

- İşletmeniz Ar-Ge' ye önem vermekte midir? Ar-Ge veya yeni ürün veya süreçler ortaya koymak adına yapılan faaliyetler için yıllık olarak bir bütçe ayırır mısınız?

-Devlet destek ve/veya teşviklerinden faydalanır mısınız? Kendinizi geliştirmek için devlet kurumları ile işbirliği yapar mısınız?

•İşletmenizin sahip olduğu patent veya marka tescil, faydalı model vs var mı? Ne zaman alındı ve sayısı nedir?

Medikal sektörde bulunan KOBİlerin devlet destek ve/veya teşviklerine karşı tutumları ve bu tutumları ArGe faaliyetlerini nasıl etkilediğinin araştırılması, ortaya konması ve önerilerde bulunulması açısından literatüre katkı sağlayacağı düşünülmektedir.

\subsection{Araştırmanın Modeli}

Çalışmada araştırma kapsamında belirlenen işletmelerle yapılan görüşmeler sonucu elde edilen veriler analiz edilerek, nitel bir çalışma gerçekleştirilmiştir.

\subsection{Verilerin Toplanması ve Analiz Yöntemi}

Çalışmanın etik unsurları dikkate alarak yapıldığını Ankara Hacı Bayram Veli Üniversitesi Etik Komisyonu 11.11.2020 tarih ve 11 sayılı toplantısında görüşülerek Etik Kurul Kararı alınmıştır. Çalışma için nitel araştırma yöntemleri ve bu yöntem türlerinden çoklu durum analizi belirlenmiştir. İşletme sahiplerinin/yöneticilerinin görüşlerinin ve düşüncelerinin daha ayrıntılı olarak anlaşılması, konunun daha derinlemesine ele alınarak yüz yüze soru-cevap ilişkisi içerisinde irdelenmesi için nitel araştırma yöntemlerine başvurulmuştur. Çoklu durum analizi yöntemine başvurulmasının sebebi ise birden fazla durumun ele alınarak analiz edilecek olmasıdır. Çoklu durum analizinin amacı konuya ilişkin farklı bakış açıları ortaya koymaktır (Creswell, 2013:99). Görüşme soruları yarı yapılandırılmış ve açık uçlu olarak oluşturulmuştur. Görüşmeler işletme sahiplerinin kendi yerlerinde, ortalama 55 dakikalık bir süre içerisinde bizzat araştırmacılar tarafından yapılmıştır. Görüşme yapılan işletmecilerin onayları alındıktan sonra ses kayıt cihazı ile görüşmeler kayıt altına alınmıştır. Çalışmada katılımcıların kişisel bilgilerinin gizliliği noktasında her bir işletme alfabetik sıraya göre (A, B, C,..) kodlanarak ele alınacaktır. 


\section{4. Çalışmanın Evreni ve Örneklemi}

Çalışmanın evrenini İstanbul ve Ankara'da bulunan, medikal sektörde faaliyet gösteren KOBİler oluşturmaktadır. Ostim Medikal Küme ve KOSGEB ile görüşülerek medikal sektörde faaliyet gösteren işletmelere ulaşılmıştır. Ulaşılan işletmeler arasından görüşme yapmayı kabul eden yedi işletme ile görüşme sağlanmıştır.

Tablo 3: Katılımcı Bilgileri

\begin{tabular}{|l|l|l|l|l|l|l|l|}
\hline $\begin{array}{l}\text { Katılımc1 } \\
\text { Kodu }\end{array}$ & Yer & Cinsiyet & Yaş & İş Deneyimi & Çalışan Sayısı & $\begin{array}{l}\text { Yıllık Net } \\
\text { Satış (TL) }\end{array}$ & Eğitim Seviyesi \\
\hline A & İstanbul & Erkek & 53 & 36 & 52 & 1,5 milyon & Lisans \\
\hline B & İstanbul & Erkek & 65 & 36 & 83 & 4,5 milyon & Doktora \\
\hline C & İstanbul & Erkek & 37 & 13 & 18 & 2 milyon & Yüksek Lisans \\
\hline D & Ankara & Erkek & 56 & 30 & 31 & 2,5 milyon & Lisans \\
\hline E & Ankara & Erkek & 51 & 27 & 29 & 7 milyon & Lisans \\
\hline F & Ankara & Erkek & 48 & 13 & 15 & 6,5 milyon & Lise \\
\hline G & Ankara & Erkek & 45 & 16 & 17 & 4,5 milyon & Lisans \\
\hline
\end{tabular}

Tablo 3'de katılımcılara ait bilgiler bulunmaktadır. Tamamı işletme sahiplerinden oluşan katılımcıların hepsi erkek olup yaşları 36 ile 64 arasındadır. Eğitim düzeyleri ise 4'ü lisans olmak üzere, diğer katılımcılar lise, yüksek lisans ve doktora arasında çeşitlilik göstermektedir. İşletmelerin çalışan sayısı ve yıllık net satışları ise KOBİ olma şartlarını ${ }^{4}$ karşılayıp karşılamadığını göstermektedir. Katılımcıları iş deneyim süreleri en az 12 yıl olmakla birlikte en fazla 35 yıldır. Katılımcıların 3'ü İstanbul'da 4'ü Ankara'da bulunmaktadır.

\section{Bulgular}

Çalışma kapsamında görüşülen katılımcılara tablo 3'de gösterildiği gibi kişisel bilgileri ve işletmelerine özgü bilgiler sorulduktan sonra yenilik faaliyetlerinin sorgulanmasına yönelik sorular yöneltilmiştir. Çalışmaya katılan işletmelerin son 3 yıl içerisinde ortaya koydukları herhangi bir yeni ürün veya süreç olup olmadığ1 sorgulanmıştır. Literatürde ki yenilik ölçeklerini incelediğimizde işletmelerin son 3 yıl içerisinde yeni ürün veya süreç ortaya koymaları onların yenilikçi bir işletme olduklarını göstermektedir (De Jong ve Marsili, 2006). A ve $C$ işletmelerinin hem yenilik planı yapma noktasında hem de yeni ürün ve süreç ortaya koyma noktasında herhangi bir faaliyette bulunmamaktadır. A ve $C$ işletmeleri hariç diğer işletmeler yenilik planı yapmaktadırlar. D işletmesinin sadece ürün yenilikçiliği, A işletmesinin sadece süreç yeniliği, B, E, F ve G işletmelerinin ise hem ürün hem de süreç yenilikçiliği bulunmaktadır. Çalışma kapsamında görüşülen işletmelerin çoğunluğu yurt dışı pazara yönelik üretim yapan ihracatçı işletmeler oldukları görülmektedir. Dolayısıyla iç pazarla yetinmeyip dış pazara yönelik de ürün geliştirme, üretme çabası içerisinde olan girişimcilik yönelimli yüksek işletmeler olarak tanımlanabileceklerdir. B ve C işletmesi Ar-Ge'ye yönelik bütçe ayıran ve patent sahibi olan işletmelerdir. B işletmesi devlet desteklerinden yararlanarak Ar-Ge'ye bütçe ayıran ve 70 adet patente sahip bir işletmedir. C işletmesi ise devlet desteklerinden yararlanmadan kendi imkanları ile Ar-Ge'ye bütçe ayıran ve 2 adet patenti olan bir işletmedir.

\footnotetext{
4 "Küçük ve Orta Büyüklükteki İşletmelerin Tanımı, Nitelikleri ve Sınıflandırılması Hakkında Yönetmelik" ile KOBI'ler, yılda en fazla 250 kişi istihdam eden, yıllık net satış hasılatı veya mali bilançosundan herhangi biri 125 milyon TL'sini aşmayan, mikro, küçük ve orta büyüklükteki işletme olarak sınıflandırılan ekonomik birimler veya girişimler olarak tanımlanmaktadır (www.kosgeb.com.tr).
} 
A. Yalçın - B. Çetin 13/3 (2021) 2607-2622

Tablo 4: Katılımcı Faaliyet Bilgileri

\begin{tabular}{|l|l|l|l|l|l|l|l|l|}
\hline $\begin{array}{l}\text { Katılımc1 } \\
\text { Kodu }\end{array}$ & $\begin{array}{l}\text { Yenilik } \\
\text { Planı }\end{array}$ & $\begin{array}{l}\text { Ürün } \\
\text { /Süreç } \\
\text { Yeniliği }\end{array}$ & $\begin{array}{l}\text { Yenilik } \\
\text { Uzmanı } \\
\text { Var/Yo } \\
\mathrm{k}\end{array}$ & $\begin{array}{l}\text { Ulusal } \\
\text { ve/veya } \\
\text { Uluslararas } \\
\text { Fuar } \\
\text { Katılımı }\end{array}$ & $\begin{array}{l}\text { Yurtdışı } \\
\text { Satış } \\
\text { Var/Yo } \\
\mathrm{k}\end{array}$ & $\begin{array}{l}\text { Ar- } \\
\text { Ge'ye } \\
\text { bütçe } \\
\text { ayırma }\end{array}$ & $\begin{array}{l}\text { Patent } \\
\text { /Faydalı } \\
\text { Model }\end{array}$ & $\begin{array}{l}\text { Devlet } \\
\text { desteklerinde } \\
\text { n faydalanma }\end{array}$ \\
\hline A & - & S & - & - & Yok & - & - & - \\
\hline B & + & Ü+S & + & + & Var & + & P (70) & $\begin{array}{l}\text { KOSGEB, } \\
\text { TÜBİTAK }\end{array}$ \\
\hline C & - & - & + & - & Yok & - & - & - \\
\hline D & + & Ü & - & + & Var & - & - & - \\
\hline E & + & Ü+S & + & + & Var & + & P (2) & - \\
\hline F & + & Ü+S & - & + & Var & - & - & - \\
\hline G & + & Ü+S & + & + & Var & + & FM & - \\
\hline
\end{tabular}

Katılımcıların yenilik faaliyetlerine ilişkin sorulan sorular (-Yenilik yapmaya zaman ayırır mısınız? Sizin için yenilik yapmak neden önemlidir? -Son 3 yıl içerisinde ortaya koymuş olduğunuz ürün velveya süreç yeniliğiniz var mı?) neticesinde, yeniliğe oldukça önem vermekte, yeniliği olmazsa olmaz bir faaliyet olarak görmekte ve bu şekilde görme nedenlerini ise Tablo 5'de gösterilmekte olan temalar aracılı̆̆ ile belirtmektedirler.

Tablo 5: İşletmeler için yenilik faaliyetlerinin önemine yönelik temalar

\begin{tabular}{|l|l|l|l|}
\hline & Temalar & F & $\mathbf{\%}$ \\
\hline $\mathbf{1}$ & Rekabet (B, C, D, E, F, G) & 6 & 85,7 \\
\hline $\mathbf{2}$ & Teknolojiyi yakalama (B, C, D, E, F, G) & 6 & 85,7 \\
\hline $\mathbf{3}$ & Ürün-süreç iyileştirme, geliştirme (A, B, D, E, F, G) & 6 & 85,7 \\
\hline $\mathbf{4}$ & Kalite (B, D, E, F, G) & 5 & 71,4 \\
\hline $\mathbf{5}$ & Müşteri memnuniyeti (D, E, F, G) & 4 & 57,1 \\
\hline
\end{tabular}

(D) Bir insanın hayatta kalabilmesi için nasıl kana gerek varsa firmaların ayakta kalabilmesi, yurtdışı ile rekabet edebilmesi için de yenilik olmazsa olmazdır, tabiri caizse firmayı ayakta tutan kandır. Ve bizim gibi firmalar devamlı yeniliğe konsantrasyon olmak zorunda. Hem yeni teknolojiyi yakalamak hem de daha kaliteli ürünler ortaya çıkarabilmek için yenilik yapmak zorundayız, başka çaremiz yok yapmazsak yok oluruz. (G) Yeniliğe fazlasıyla önem veririz. Medikal alanda çalışan bütün firmalar için yenilik şart çünkü dünya ile rekabet ediyorsunuz. Her gün sizin ürünlerinizde yeni bir teknolojik olay ortaya çıkıyor. Sürekli yurtdışına seyahat eden çalışanlarımız var ve dünyada ki yenilik veya yeni şeyleri görebiliyorlar. Bundan dolayı ürünlerimiz sürekli gelişiyor değişiyor. Kullandığımız malzemeler de sürekli değişiyor. Kaldı̆̆ımız yerde devam edersek müşteri ne zaman gelir diye beklemek zorunda kalırız. (E) Yenilik yapmak zorundasınız. Yenilik yapmazsanız yerinde sayıyorsunuz. Yenilik düşüncesi fikri biz de her zaman var ne yapabiliriz düşüncesi. Bize gelen müşteri kalifiye bir müşteri konusuna da hakim, ürünü verebileceğiniz en kaliteli şekilde ve en uygun fiyata vermek zorundasınız. Burada farklılıklar, yenilikler önemli oluyor işte. (B) Ayrı bir şirket var bunun için. Aslında teknokent içinde bulunan ofis ayr bir şirket olarak görüyoruz. Çok önemli bu. Hem siz rakiplerinizle aynı çevredesiniz. Onlardan bir adım daha ileride olmak için bu önemli. Eskisi gibi değil artık. Biz şirketi kurdŭ̆umuzda nasıldı şimdi nasıl. Üç kişiydik şimdi 70 kişiyiz. Yenilik yapmazsan zaten kaybedersin. Bizde ürün yeniliği daha önemli. Ayrıcalıkl ürünleri geliştirmede bunlarn sürdürülmesinde yenilik olmazsa olmaz zaten. (A) Yenilik yapma konusunda risk alacak durumda değiliz şu anda. Riske girmemek adına şu anda yenilik faaliyeti içerisinde bulunmuyoruz ama ileride yeni ürün üretmek için geleceğe yönelik planlarımız var. Mühendislerimiz var, 4 tane, alanları ile ilgili gelişmeleri takip etmeleri için eğitim aldırmaya başladık. (C) Bizim için şu anda kendimiz adına yaptığımız en büyük yenilik ihracata başlıyor olmamız. Karşımıza çıkan bir fırsat ile başlıyoruz bakalım. Sonrasında yenilik yapmak zorunda olduğumuzun farkındayız ama dediğimiz gibi yeni başlıyoruz şu anda hali hazırda bir şey yok. 
A. Yalçın - B. Çetin 13/3 (2021) 2607-2622

Tablo 6: İşletmelerin önemli yenilik göstergelerinden biri olan Ar-Ge faaliyetlere verilen önemin sorgulanması

\begin{tabular}{|l|l|l|l|}
\hline & Temalar & $\mathbf{F}$ & $\%$ \\
\hline $\mathbf{1}$ & Önem veriyoruz/Önemli olduğunu düşünüyoruz (A, B, C, D, E, F, G) & 7 & 100 \\
\hline $\mathbf{2}$ & Yenilik (B, C, E, G) & 4 & 57,1 \\
\hline $\mathbf{3}$ & Kalite Standartları Yakalamak (A, B, E, G) & 4 & 57,1 \\
\hline $\mathbf{4}$ & Rakiplerden Öne Geçme İsteği, Rekabet (C, B, E) & 3 & 42,8 \\
\hline $\mathbf{5}$ & Teknolojik Liderlik (B, E, G) & 3 & 42,8 \\
\hline $\mathbf{6}$ & Bütçe Sorunu (D, F, G) & 3 & 42,8 \\
\hline
\end{tabular}

Katılımcıların Ar-Ge faaliyetlerini nasıl gördükleri, Ar-Ge faaliyeti yapıp yapmadıklarının anlaşılması üzerinde sorulan soru (İşletmeniz Ar-Ge' ye önem vermekte midir? Ar-Ge veya yeni ürün veya süreçler ortaya koymak adına yapılan faaliyetler için yıllık olarak bir bütçe ayırır mısınız?) neticesinde, Ar-Ge faaliyetlerini fazlasıyla önemsediklerini fakat kaynak yetersizliğinden dolayı gereken önemi veremedikleri anlaşılmaktadır. Katılımcıların, işletmelerin Ar-Ge faaliyetlerine neden önem vermeleri gerektiğine yönelik cevapları Tablo 6'de gösterilmektedir.

(E) Ar-Ge'ye ve teknolojik liderliğe çok önem veriyoruz. Kaliteli mal üretmek için, Avrupa kriterlerine ulaşmak için ArGe şart. Ayrıca Ar-Ge yapmazsak yenilik yapamayız yani yenilik için olmazsa olmaz bir şey bizim için. Sürekli daha iyisini aradığımız için araştırıyoruz daha iyisini yapmaya ürünlerimizi süreçlerimizi geliştirmeye çabalıyoruz. (G) ArGe'ye önem vermek ve bütçe ayırmak zorundayız yoksa yeni ürün geliştiremeyiz. Teknolojik liderlik konuları da mesela aynı şekilde. Daha iyisini yapmak için çabalıyoruz. Ama tabi bu konu Türkiye'nin muzdarip olduğu konulardan biri. Bizde ki Ar-Ge açıkçası kendi çabamızla. Bulunan ürünün üzerinde çok çalışıldığı için çok fazla kısıtlı kalınıyor. Ülke genelinde büyük firmalara baktı̆̆ınızda yıllık bütçelerinin \%20'lerini neredeyse Ar-Ge'ye ayırmak zorundalar ama bizim ölçekli firmalarda ne yazık ki bu pek mümkün değil. (F) Bütçemizin yettiği ölçüde önem veriyoruz. Bütçe sebebi sorunuyla çok fazla yönelemiyoruz. Çünkü Ar-Ge riskli iş para olması lazım. Bizim gibi işletmelerin de parasal durumları malum, kısıtlı. (B) Ar-Ge bizim önceliğimiz. Teknolojik gelişmelere ve teknolojik manada ilerlemelere de önem veriyoruz. Kaliteyi yakalamamı yeni ürünler üreterek veya ürünlerimizi geliştirerek rakiplerimiz ile rekabet edebilmek için bunlar elzem şeyler. Zaten bu yüzden tam 70 mühendis barındırıyoruz bünyemizde, araştırmaya odaklansınlar gelişmeleri takip etsinler istiyoruz. 70 tane patent aldık, sürekli gelişme çabasındayız. Kalite ve verimlilik bizim odak noktalarımızdan. (D) Ar-Ge'ye önem veriyoruz, rekabet ve gelişim için büyüme için oldukça önemli olduğunuz düşünüyoruz. Fakat bizim düşünmemizle olmuyor işte, bütçe yok. Ar-Ge için insan kaynağı lazım, insan kaynağı derken Ar-Ge yapacak insan kaynağından bahsediyorum, düz çalışan değil. Onları işe almak işte tutmak maliyetli bizim de kaynağımız yok. Karlılı̆ımız önümüzde engel. Karlılık olduğu zaman firmanın yürüyüşü değişir. O zaman insan kaynağı oluşur, mühendisi aldınız çay getirmesini beklemeyeceksin adamdan Ar-Ge bekleyeceksin. Para insanı akıllı yapar zihin açılır. Para olursa Ar-Ge'de olur insan kaynă̆ı da olur.

Tablo 7: İşletmelerin devlet desteklerine olan bakış açısının sorgulanması

\begin{tabular}{|l|l|l|l|}
\hline & Temalar & F & \% \\
\hline $\mathbf{1}$ & Bürokratik Prosedür Fazlalığı (A, E, G) & 3 & 42,8 \\
\hline $\mathbf{2}$ & Bürokratik Yavaşlı (A, E, G) & 3 & 42,8 \\
\hline $\mathbf{3}$ & Güven Eksikliği (A, D, E, F, G) & 4 & 57,1 \\
\hline $\mathbf{4}$ & Destek Vericilerin Teknik Bilgi Eksikliği Olduğunun Düşünülmesi (D, E) & 2 & 28,5 \\
\hline
\end{tabular}

Katılımcı işletmelerin destek ve/veya teşvik alma amaçlı kurumlara olan bakış açısını ve devletten destek ve/veya teşvik alıp almadığını öğrenmek amacı ile sorulan soru (Devlet destek velveya teşviklerinden faydalanır mısınız? Kendinizi geliştirmek için devlet kurumları ile işbirliği yapar mısınız?) neticesinde katılımcı işletmelerin sadece bir tanesinin yoğun bir şekilde devlet desteklerinden faydalandığı görülmektedir. Katılımcıların destek ve/veya teşviklerden faydalanmama sebepleri Tablo 7'de gösterilmektedir.

(A) KOSGEB desteğine uğraştık zamanında, bürokratik süreç o kadar yoruyor ki insan bir sürü şey istiyorlar üstüne süreç çok uzun onlarla uğraşmaktansa destek almayız daha iyi diyoruz. (C) KOSGEB teşviklerini yeni fark ettik. Önceden 
A. Yalçın - B. Çetin 13/3 (2021) 2607-2622

ihracat yapmadığım için ilgi alanım değildi ama şimdi ihracata yönelmeyi düşünüyoruz. Yurtdışı pazarlara açılmak için gereken fuar katılımlar katalog basımı vs gibi ekstra maliyetler var KOSGEB'in bunlar için yardım ettiğini duyduk. Bu gibi faaliyetler için yararlanmayı düşünüyoruz. (B) Ciddi bir teşvik alıyoruz. Bu sayede gelişiyoruz, Ar-Ge'ye önem veriyoruz. Ar-Ge personelimize yönelik desteklerden faydalandıkça daha fazla kişi çalıştırıyoruz, 70 uzman çalışıyor ArGe birimimizde. TÜBİTAK, KOSGEB ve bakanliklardan da ciddi teşvikler aldik almaya devam ediyoruz. Hatta devlet bize ödül bile verdi. (E) Bizim en çok sıkıntı çektiğimiz nokta finans, devletin destekleri var ama bu destekleri devlet al sana destek tepe tepe kullan demiyor haklı olarak gerekçeleri var, her firmanın bir destek puan olsa ben TÜBİTAK'a gittiğimde kalkınma ajansına gittiğimde kalkınma ajansında muhatap olduğum kişi baksın. Burada kan kaybı var herkes aynı kefeye konuyor. Finans açısından çok ciddi sıkıntımız var 600 bin liralık bir proje yapıyorsunuz en az yarısını siz harcamak zorundasını, bunu harcıyorsunuz ispat ediyorsunuz ve devlette diyor ki evet gerçekten dediğin gibi harcamışsın ve yapmışsın hedefine de ulaşmışsın diyor ve vereceği parayı 1,5 yıl sonra veriyor. O yüzden desteklere sıcak bakmıyoruz artık. Mesela kümelenme üyesiyiz kümelenme güzel bir mantık ama burada da bürokratik süreçlerden dolayı ilerleyemiyor ya da olması gerekenler olamıyor. Türkiye'de sürekli bir güvensizlik var yani geri dönüş olur mu paramı alabilir miyim öyle olur mu böyle olur mu bu şekilde bakıldığında istenilen düzeye gelinemiyor tabi karşılıklı ilişki içerisinde olduklarmı ile. Bürokratik yavaşlık ve konusunda yetkin olmayan kişilerin işleri yavaşlatması sorunu var bizim gördü̆̈̈̈müz. Devletin en büyük korkusunun güvensizlik olması lazım, güven duyulan her firmaya yeterli desteği vermeli.

\section{Sonuç ve Tartışma}

Literatürde medikal sektörde bulunan KOBİ'lerin yenilik ve Ar-Ge yatırımları üzerindeki devlet desteklerinin rolüne yönelik yeteri düzeyde çalışmaya rastlanmamaktadır. Dolayısıyla çalı̧̧ma, devlet desteklerinin KOBİlerin yenilik faaliyetlerini olumlu ve önemli derecede etkileyebileceği, özellikle bilgi yoğun işletmeler olarak anılan medikal sektörde faaliyet gösteren KOBİler için yenilik ve Ar-Ge faaliyetlerinin desteklenmesinin ortaya konmasını vurgulanması açısından önemli olacağı ve ilgili literatüre katkı sağlayacağı düşünülmektedir. Çalışmada nitel araştırma yöntemlerinden faydalanarak ortaya konulan sonuçlar ile literatüre teorik açıdan katkı sağlanacağı öngörülmektedir.

Özellikle medikal sektörde faaliyet gösteren işletmeler için Ar-Ge'nin ne kadar önemli olduğu son zamanlarda tüm dünyaca yaşadığımız COVID-19 pandemi sürecinde aşı üretim faaliyetleri ile de anlaşılmaktadır. Yoğun Ar-Ge faaliyeti içerisinde olan ve yeni ürün/süreç ortaya koyan işletmelerin ülkelerine sağlayacakları katma değer ile ülke ekonomisine katkı sağlanabilecek ve rekabetçi ülke konumuna gelinebilecektir. Dolayısıyla işletmelerin yenilikçi olmaları, Ar-Ge'ye önem vermeleri sadece kendileri için değil ülke için de önemli rol oynamaktadır. Bu sebeple, üretim yapabilme potansiyeli olan yeni ürün ve/veya süreç ortaya koyabilecek ve bunun yurtdışı pazarlara ihraç edebilecek konumda olan işletmelere yönelik devlet desteklerinin arttırılması, prosedürlerin kolaylaştırılması ve işletmelere destek ve/veya teşvik veren kurumlar tarafından sürekli bir bilgi akışı sağlanması oldukça önemlidir. Rekabetçi konumda bir ülke olabilme adına, yeni ve nitelikli ürün üreten, ürettiği ürünleri dış pazarlara sunan ve böylelikle ihracat oranlarını yükselten işletmelerin sayılarının artması için çalışmalar yapılmalıdır.

Çalışma kapsamında görüşülen işletmelerin yenilik ve Ar-Ge faaliyetleri ile devlet desteklerine yönelik verdikleri cevaplar doğrultusunda ulaşılan sonuçlar aşağıdaki gibidir;

- A, C, D, E, F ve G işletmelerinin devlet desteklerinden faydalanmaması ve aralarında sadece E işletmesinin 2 adet patente sahip olması, B işletmesinin ise hem KOSGEB hem de TÜBİTAK desteklerinden faydalanarak ve 70 adet patente sahip olması devlet desteklerinin patentlere olumlu etki ettiğini gösterebilmektedir,

- Çalışma kapsamında görüşülen işletmelerin yenilik ve yenilik faaliyetlerini önemli görmelerinde rekabetçi konumda olmanın, teknolojiyi yakalamanın ve yeni ürün-süreç iyileştirme ve geliştirmenin etkili olduğu, aynı zamanda daha kaliteli ürün üretme ve müşteri memnuniyeti elde etme adına yardımcı olacağ söylenmektedir, 
- Çalışma kapsamında görüşülen işletmelerin hepsi Ar-Ge faaliyetlerinin oldukça önemli olduğunu düşünmektedirler. Ar-Ge faaliyetlerine önem vermelerinde yenilik faaliyetlerinde bulunma, yeni ürünsüreç ortaya koyma ve kalite standartlarını yakalama isteğinin etkili olduğu görülmektedir. Ayrıca ArGe'ye faaliyetlerinde bulunarak ürünlerinde yenilik yaparak veya geliştirerek veya tamamen yeni bir ürün ortaya koyarak rakiplerinden öne geçeceklerini ve böylelikle daha rekabetçi konuma yükseleceklerini düşünmektedirler. Aynı zamanda teknolojik liderlik konusuna verdikleri önemi de belirtmişlerdir.

- Ar-Ge faaliyetlerini önemli görmelerine rağmen kaynak ve bütçe sıkıntısından dolayı Ar-Ge faaliyeti içerisinde bulunamadıklarını dile getirmişlerdir,

- Bütçe ve kaynak sıkıntısı yüzünden Ar-Ge faaliyetleri içerisinde bulunamayan işletmelerin devlet desteklerine karşı da olumlu bir bakış açısı içerisinde olamadıkları anlaşılmaktadır. Bunun en büyük sebepleri olarak ise bürokratik prosedürlerin oldukça fazla olmasını, bürokratik yavaşlı̆̆ı ve destek veren kurum ve kuruluşlar ile karşlıklı bir güvensizlik ilişkisi düşüncesini öne sürmüşlerdir. Genel olarak kurum ve kuruluşların destek almak isteyen girişimlere yönelik güven eksikliği olduğunu, bu konuda belki de haklı olduğunu fakat her girişimin aynı koşullarda değerlendirilmemesi gerektiğini düşünmektedirler. Girişimlerin daha önce yapmış oldukları projeler veya faaliyetler göz önünde bulundurularak verilecek destek süreçleri ve miktarlarında ayarlama yapılması ve özellikle Ar-Ge faaliyetleri noktasında girişimlerin performanslarının takip edileceği bir sistem oluşturulması girişimler için faydalı olabilecektir.

Görüşülen işletmelerin verdikleri cevaplardan ve literatürdeki çalışmalarında incelenmesi ile medikal sektörde yer alan KOBİ'lerin yenilik faaliyetlerine ve yenilik faaliyetlerini arttırmaya yönelik öneriler çalışma kapsamında şu şekilde ele alınmaktadır;

- Medikal sektörde faaliyet gösteren veya gösterecek yenilikçi işletmelerin bir araya gelebilmelerini, işbirliği yapabilmelerini sağlayacak platformların oluşturulması, etkinlikler yapılması,

- Yurtiçinde ve yurtdışında bulunan, sektöre katkısı olan girişimcilerin, bilim adamlarının, sağlık çalışanlarının ve tüm paydaşların yenilikçi girişimciler ile etkileşim halinde olabilecekleri, fikir alışverişi yapabilecekleri ortamların oluşturulması,

- Sektöre özgü girişim kümelenmelerinin birbirleri arasındaki ilişkilerin arttırılması ve bu kümelenmelere yönelik desteklerin arttırılması,

- Teknoparklara ve kuluçka merkezlerine yönelik destek ve/veya teşviklerin arttırılması, yenilikçi girişimlerin bu merkezler noktasında bilgilendirilmesi,

- Yenilikçi girişimlerin yenilik faaliyetlerine ilişkin destek ve/veya teşvikte bulunan kurum ve kuruluşların değerlendirme ve destek süreçlerinde iyileştirmeler yapması,

- Destek ve/veya teşvik programı sürecinde uygulanması gereken bürokratik prosedürlerin azaltılmasına ve sürecin daha hızlı işlemesine yönelik çalışmalar yapılması,

- Yenilikçi girişimlere yönelik farklı destek ve/veya teşvik programları uygulanması, değerlendirme koşullarının girişimlerin mevcut pozisyonları ve kapasiteleri gözetilerek belirlenmesi,

- Yenilikçi girişimlerin destek ve/veya teşvik programlarına ilişkin bilgilendirmelerin arttırılması,

- Kamu-Üniversite-Sanayi işbirliğinin arttırılması, geliştirilmesi ve daha etkin hale getirilmesi,

- Medikal KOBİlerin yenilik faaliyetlerine ilişkin eğitim faaliyetlerinin arttırılması, gereken konularda danışmanlık hizmetleri verilerek desteklenmesi,

- Medikal KOBI'lerin yenilikçi fikirlerini değerlendirecek mühendisler, uzmanlar ve sağlık çalışanları gibi fikirlerin ticarileşmesine katkı sağlayacak taraflar arasında işbirliklerin arttırılması, desteklenmesi ve özendirilmesi ile birlikte işletmelerin daha fazla yenilikçi olmalarını sağlanabilecektir. İşletmeler aldıkları destekler ile birlikte kısıtlı kaynakları sebebiyle yapamadıkları faaliyetleri gerçekleştirme imkânı elde edebileceklerdir. Nitelikli ve Ar-Ge noktasında uzman insan kaynaklarını bünyelerinde barındırarak daha fazla araştırma yapma imkânı sağlayabileceklerdir.

Çalışma sonuçları, literatürde devlet destek ve teşviklerinin KOBI'ler için önemine ve bu desteklerin KOBİlerin yenilik ile Ar-Ge faaliyetlerini olumlu yönde etkilediğine yönelik yapılan çalışmaların (North, Smallbone ve Vickers, 2001; Kaufmann ve Tödtling, 2002; Gülmez ve Yalman, 2010; Türkoğlu ve Çelikkaya, 
A. Yalçın - B. Çetin 13/3 (2021) 2607-2622

2011; Kang ve Park, 2012; Kolisnichenko, 2017; Seo, J. H., ve Cho, 2020) sonuçları ile örtüşmektedir Dolayısıyla sonuçlar aynı zamanda literatürü desteklemektedir.

\section{Kisitlar}

Çalışmanın gelecekteki araştırmalar için bazı sınırlamaları vardır. Bu çalışma Ankara ve İstanbul illerinde bulunan medikal KOBI'lerin yenilik faaliyetlerinde devlet desteklerinin etkisi üzerine olduğundan, ilk kısıt, bulguların büyük ölçekli işletmelere uygulanamaz olmasıdır. Bir diğer kısıt ise çalışmanın medikal sektörde faaliyet gösteren işletmeler üzerine yapılmış olmasıdır. İleride yapılacak çalışmaların farklı iller ve/veya bölgelerde yapılması ile farklı sonuçlar elde edilebilir veya çalışmanın sonuçlarına benzer sonuçlar elde edilerek hem çalışma hem de literatür desteklenebilir. Dolayısıyla çalışmada ulaşılan sonuçların ileride yapılacak çalışmalara 1şık tutacağı düşünülmektedir. Özetle, çalışma bulguları tüm büyüklükteki işletmeler ve farklı sektörler için oluşturulabilir ve uygulanabilir değildir, oysa bulgular benzer bağlamlarda ve görüşülen işletme türlerine yönelik daha fazla araştırma için bir temel olarak kabul edilebilir.

\section{Kaynakça}

Almus, M. and Czarnitzki, D. (2003). The effects of public R\&D subsidies on firms' innovation activities: The case of Eastern Germany. Journal of Business \& Economic Statistics, 21(2), 226-236. https://doi.org/10.1198/073500103288618918

Antonia,J. and Zamora,C.(2000). Investment in health and Economic Growth: A Perpective From Latin America and the Caribbean. XXXV.Meeting of the Advisory Committe on health Research, Havana, Cuba.

Auer, A. and Jarmai, K. (2018). Implementing responsible research and innovation practices in SMEs: Insights into drivers and barriers from the Austrian medical device sector. Sustainability, 10(17), 1-18. https://doi.org/10.3390/su10010017

Baldwin, J. R. and Johnson, J. (1995). Human capital development and innovation the case of training in small and medium sized firms. Statistics Canada Working Paper, 74. http://dx.doi.org/10.2139/ssrn.3138

Bergsland, J., Elle, O. J. and Fosse, E. (2014). Barriers to Medical Device Innovation. Medical Devices: Evidence and Research, 7, 205-209. https://doi.org/10.2147/MDER.S43369

Bérubé, C. and Mohnen, P. (2009). Are firms that receive R\&D subsidies more innovative?. The Canadian Journal of Economics, 42(1), 206-225. https://doi.org/10.1111/j.1540-5982.2008.01505.x

Bronzini, R. and Piselli, P. (2016). The impact of R\&D subsidies on firm innovation. Research Policy, 45(2), 442457. https://doi.org/10.1016/j.respol.2015.10.008

Claire, R.B. (2004). Thanks to new technology, the medical instruments industry produces a wealth of products. The Daily Record, February, 1.

Creswell, J. W. (2013). Nitel araştırma yöntemleri. M. Bütün and SB Demir, Çev.(Eds.). İstanbul: Siyasal Kitapevi.

Daiberl, C. F., Oks, S. J., Roth, A., Möslein, K. M. and Alter, S. (2019). Design principles for establishing a multisided open innovation platform: Lessons learned from an action research study in the medical technology industry. Electronic Markets, 29(4), 1-18. https://doi.org/10.1007/s12525-018-0325-2

Davey, S.M., Brennan M., Meenan B.J. and McAdam,R. (2011). Innovation in the medical device sector: An open business model approach for high-tech small firms. Technology Analysis \& Strategic Management, 23(8), 807-824. https://doi.org/10.1080/09537325.2011.604152

De Jong, J. P. and Marsili, O. (2006). The fruit flies of innovations: A taxonomy of innovative small firms. Research Policy, 35(2), 213-229. https://doi.org/10.1177/0266242606069268

Deloitte (2021). Digital R\&D: Transforming The Future of Clinical Development. https://www2.deloitte.com/tr/tr/pages/life-sciences-and-healthcare/articles/digital-research-anddevelopment-clinical-strategy.html Acces Date: 30.04.2021

Dosi, G. (1988). Sources, procedures, and microeconomic effects of innovation. Journal of Economic Literature, 26(3), 1120-1171. 
A. Yalçın - B. Çetin 13/3 (2021) 2607-2622

Efrat, K., Gilboa, S. and Yonatany, M. (2017). When marketing and innovation interact: The case of born-global firms. International Business Review, 26(2), 380-390. http://dx.doi.org/10.1016/j.ibusrev.2016.09.006

Eisenhardt, K.M. and Martin, J.A. (2000). Dynamic Capabilities: What Are They? Strategic Management Journal, 21(10-11), $\quad$ 1105-1121. $\quad$ https://doi.org/10.1002/1097-0266(200010/11)21:10/11<1105::AIDSMI133>3.0.CO;2-E

Ekonomik İşbirliği ve Kalkınma Örgütü(OECD)(2002). Frascati Kılavuzu: Araştırma ve Deneysel Geliştirme Taramaları İçin Önerilen Standart Uygulama. https://www.tubitak.gov.tr/tubitak content files/BTYPD/kilavuzlar/frascati tr.pdf Erişim Tarihi: 30.04.2021

Garcia-Quevedo, J., Mas-Verdu, F. and Montolio,D. (2013). What types of firms acquire knowledge intensive services and from which suppliers?. Technology AnalysisE Strategic Management, 25(4), 473-486. http://dx.doi.org/10.1080/09537325.2013.774348

Güler, E. Ö. ve Kanber, S. (2011). İnovasyon aktivitelerinin inovasyon performansı üzerine etkileri: İmalat sanayii uygulaması. Çukurova Üniversitesi Sosyal Bilimler Enstitüsü Dergisi, 20(1), 61-76.

Gülmez, M. ve Yalman, İ. N. (2010). Yatırım teşviklerinin bölgesel kalkınmaya etkileri: Sivas ili örneği. Atatürk Üniversitesi İktisadi ve İdari Bilimler Dergisi, 24(2), 235-257.

Gültekin, A. ve Onuk, M. (2020). Bursa Otomotiv Sanayisinde İnovasyonun Şirket Performansı Üzerine Etkisini İnceleyen Bir Araştırma. Ekonomi ve Sosyal Araştırmalar Dergisi, 7(13), 54-65.

Hughes, M. and Morgan, R. E. (2007). Deconstructing the relationship between entrepreneurial orientation and business performance at the embryonic stage of firm growth. Industrial Marketing Management, 36(5), 651-661. http://dx.doi.org/10.1016/j.indmarman.2006.04.003

Hyytinen, A. and Toivanen, O. (2005). Do financial constraints hold back innovation and growth?Evidence on the role of public policy. Research Policy, 34(9), 1385-1403. https://doi.org/10.1016/j.respol.2005.06.004

Kang, K. N. and Park, H. (2012). Influence of government R\&D support and inter-firm collaborations on innovation in Korean biotechnology SMEs. Technovation, 32(1), 68-78. https://doi.org/10.1016/j.technovation.2011.08.004

Karhunen, H. and Huovari, J. (2015). R\&D subsidies and productivity in SMEs. Small Business Economics, 45(4), 805-823. https://doi.org/10.1007/s11187-015-9658-9

Kaufmann, A. and Tödtling, F. (2002). How effective is innovation support for SMEs? An analysis of the region of Upper Austria. Technovation, 22(3), 147-159. https://doi.org/10.1016/S0166-4972(00)00081-X

Kılıçarslan, M. ve Takkasız, B. (2019). Dünyada ve Türkiye'de Tıbbi Cihaz Sektöründe Pazarlamanın Önemi. Avrupa Bilim ve Teknoloji Dergisi, (17), 966-971. https://doi.org/10.31590/ejosat.647581

Kiper, M. (2018). Dünyada ve Türkiye'de tıbbi cihaz sektörü ve strateji önerisi. Türkiye Teknoloji Geliştirme Vakfı. Ankara.

Kleer, R. (2010). Government R\&D subsidies as s signal for private investors. Research Policy, 39(10), 1361-1374.

Klette, T. J. and Moen, J. (2011). R\&D investment response to R\&D subsidies: A theoretical analysis and a microeconometric study. World Review of Science Technology and Sustainable Development, 9(2/3/4), 1-35. https://doi.org/10.2139/ssrn.1940407

Knight, G.A. and Cavusgil, S.T. (2004). Innovation Organizational Capabilities, and Born Global Firm. Journal of International Business Studies. 35, 124-141.

Koga, T. (2005). R\&D subsidy and self-financed R\&D: The case ofJapanese high-technology start-ups. Small BusinessEconomics, 24(1), 53-62. https://doi.org/10.1007/s11187-005-3096-Z

Kolisnichenko, P. (2017). Government support for small and medium-sized business and innovative activities. Baltic Journal of Economic Studies, 3(4), 115-119.

Köker, A. R. ve Alan, H. (2021). COVID-19 Küresel Salgın Sürecinin İşletmelerin Teknik Yenilik Faaliyetlerine Yansımaları: Patent Başvuruları Üzerine Bir Araştırma. İşletme Araştırmaları Dergisi, 13(1), 267-280. https://doi.org/10.20491/isarder.2021.1133 
A. Yalçın - B. Çetin 13/3 (2021) 2607-2622

Köse, N. G. ve Çifter, A. S. (2018). Türkiye tıbbi cihazlar sektörüne yönelik bir inceleme: Ürün geliştirme süreçlerinin insan merkezli tasarım üzerinden değerlendirilmesi. Online Journal of Art and Design, 6(5), 239-262.

Larsen, P. and Lewis, A. ( 2007). How Award-Winning SMEs Manage the Barriers to Innovation. Creavity and Innovation Management, 16(2), 142-151. https://doi.org/10.1111/j.1467-8691.2007.00428.x

Lukács, E. (2005). The economic role of SMEs in world economy, especially in Europe. European Integration Studies, 4(1), 3-12.

Lumpkin, G. T. and Dess, G. G. (1996). Clarifying the entrepreneurial orientation construct and linking it to performance. Academy of management Review, 21(1), 135-172. https://doi.org/10.5465/amr.1996.9602161568

Manez, J.A., Rochina-Barrachina, M. E., Sanchis-Llopis, J.A. and Vicente, O. (2014). Financial Constraitns and R\&D and Exporting Strategies for Spanish Manufacturing Firms. Industrial and Corporate Change, 23(6), 1563- 1594.

Meuleman, M. and De Maeseneire, W. (2008). Do R\&D Subsidies Affect SMES'Access To External Financing. Vlerick Leuven Gent Working Paper Series, 2008/12

North, D., Smallbone, D., \& Vickers, I. (2001). Public sector support for innovating SMEs. Small Business Economics, 16(4), 303-317. https://doi.org/10.1023/A:1011164801073

Organisation for Economic Co-operation and Development(OECD) (2018). Oslo Manual 2018: Guidelines for Collecting, Reporting and Using Data on Innovation, 4th Edition, The Measurement of Scientific, Technological and Innovation Activities, OECD Publishing, Paris/Eurostat, Luxembourg. https://doi.org/10.1787/9789264304604-en

Okamuro, H., Nishimura, J., Colombo, M. and Stam, E. (2019). Promoting SME R\&D and Innovation. T20 Japan 2019 Policy Brief. https:/t20japan.org/wp-content/uploads/2019/03/t20-japan-tf9-2-promotingresearch-development-innovation-smes.pdf Erişim Tarihi: 25.05.2021

Pullen, J. J. A., Weerd-Nederhof, P. C., Groen, A. J. and Olaf, F. A. M. (2012). Open innovation in practice: goal complementarity and closed NPD networks to explain differences in innovation performance for smes in the medical devices sector. Journal of Product Innovation Management, 29(6), 917-934. https://doi.org/10.1111/j.1540-5885.2012.00973.x

Rammer, C., Czarnitzki, D. and Spielkamp, A. (2009). Innovation success of non-R\&D-performers: substituting technology by management in SMEs. Small Business Economics, 33(1), 35-58. https://doi.org/10.1007/s11187-009-9185-7

Resmi Gazete (2010). Küçük ve orta ölçekli işletmeleri geliştirme ve destekleme idaresi başkanlığı (KOSGEB), Ar-Ge, Ür-Ge ve İnovasyon destek programı. Sayı: 27612

Rialp, A., Rialp, J., Urbano, D. and Vaillant, Y. (2005). The born-global phenomenon: A comparative case study research. Journal of International Entrepreneurship, 3(2), 133-171. https://doi.org/10.1007/s10843-005-4202$\underline{7}$

Sass, M. (2011). Internationalisation of innovative SMEs in the Hungarian medical precision instruments industry. Post-Communist Economies, 24(3), 365-382. https://doi.org/10.1080/14631377.2012.705470

Scherer, F.M. (1980). Industrial Market Structure and Economic Performance. Rand McNally, Chicago.

Seo, J. H. and Cho, D. (2020). Analysis of the Effect of R\&D Planning Support for SMEs Using Latent Growth Modeling. Sustainability, 12(3), 1018. https://doi.org/10.3390/su12031018

Stone, A., Rose, S., Lal B. and Shipp, S. (2008). Measuring innovation and intangibles: A business perspective. Science and Technology Policy Institute, Washington.

Taban, S. (2006). Türkiye'de Sağlık ve Ekonomik Büyüme Arasındaki Nedensellik İlişkisi. Sosyoekonomi, 4(4), 31-46.

Tarım, M. (2014). Sağlık Politikaları ve Ar-Ge. Sağlık Düşüncesi Platformu ve Tıp Kültürü Platformu. https://www.sdplatform.com/Dergi/810/Saglik-politikalari-ve-Ar-Ge.aspx Erişim Tarihi: 30.04.2021

Ticaret bakanlığ1 (2021). Destekler. https://www.ticaret.gov.tr/destekler Erişim Tarihi: 04.05.2021 
A. Yalçın - B. Çetin 13/3 (2021) 2607-2622

Tur-Mas, A. and Soriano, R. D. (2014). The level of innovation among young innovative companies: The impact of knowledge-intensive services use, firm charactersitics and the entrepreneur attributes. Services Business, 8, 51-63. https://doi.org/10.1007/s11628-013-0186-x

Türkiye Bilimsel ve Teknik Araştırma Kurumu(TÜBİTAK)(2021). Destekler. https://www.tubitak.gov.tr/tr/destekler/sanayi/ulusal-destek-programlari Erişim Tarihi:04.05.2021

Türkiye Cumhuriyeti Kalkınma Bakanlığı (2018). On Birinci Kalkınma Planı(2019-2023): Ar-Ge ve Yenilik Ekosisteminin Güçlendirilmesi Özel İhtisas Komisyonu Raporu.

Türkiye İstatistik Kurumu(TUIK)(2020). Küçük ve Orta Büyüklükteki Girişim İstatistikleri,2019. https://data.tuik.gov.tr/Bulten/Index?p=Kucuk-ve-Orta-Buyuklukteki-Girisim-Istatistikleri-2019-37548 Erişim Tarihi:30.04.2021

Türkiye İstatistik Kurumu (2021). Araştırma- Geliştirme Faaliyetleri Araştırması, 2019. https://data.tuik.gov.tr/Bulten/Index?p=Arastirma-Gelistirme-Faaliyetleri-Arastirmasi-2019-33676 Erişim Tarihi: 30.04 .2021

Türkiye İlaç ve Tibbi Cihaz Kurumu (2015). Türkiye Tıbbi Cihaz Sektörü Strateji Belgesi ve Eylem Planı(20162020). https://www.resmigazete.gov.tr/eskiler/2010/06/20100615-4.htm Erişim Tarihi: 03.05.2021

Türkoğlu, M. ve Çelikkaya, S. (2011). Türkiye'de KOBI'lere yönelik Ar-Ge destekleri. Uluslararası Alanya İşletme Fakültesi Dergisi, 3(2), 56-71.

Vrontis, D., Basile, G., Andreano M. S., Mazzitelli A. and Papasolomou I. (2020). The profile of innovation driven Italian smes and the relationship between the firms' networking abilities and dynamic capabilities. Journal of Business Research, 114, 313-324. https://doi.org/10.1016/j.jbusres.2020.04.009

Walters, A., Thomas, N., Brown, R. and Lewis, A. (2001). Barriers to effective product development within SMEs in the medical manufacturing sector. Manufacturing information systems proceedings of the Fourth SME International Conference.

Xin, J. Y., Yeung, A. C.L. and Cheng, T.C.E. (2010). First to market: Is technological innovation in new product development profitable in health care industries?. International Journal Production Economics, 127, 129135. https://doi.org/10.1016/j.ijpe.2010.05.004

Yülek, M. ve Daş, G.S.(2016). KOBİlerin Yenilikçilik Kapasitelerini Geliştirecek Desteklerin Tasarımına Yönelik Kavramsal Bir Model Önerisi: Yenilikçilik Profillerine Dayalı Bir Yaklaşım. Ege Akademik Bakış, 16(3), 555-572. https://doi.org/10.21121/eab.2016319973

Zeng, S.X., Xie, X.M. and Tam, C.M.(2010). Relationship between cooperation networks and innovation performance of SMEs. Technovation, 30(3), 181-194. https://doi.org/10.1016/j.technovation.2009.08.003 